\title{
Апостол Павел в Иудее: последний визит
}

\author{
В.Н. Парфенов, Е.В. Литовченко \\ Саратовская православная духовная семинария, \\ Россия, 410028, г. Саратов, ул. Мичурина, 92; \\ Пензенская духовная семинария, \\ Россия, 440023, г. Пенза, ул. Перекоп, 4; \\ Белгородский государственный национальный исследовательский университет, \\ Россия, 308015 г. Белгород, ул. Победы, 85 \\ E-mail: vparfenov@list.ru, Litovchenko@bsu.edu.ru
}

\begin{abstract}
Аннотация. После ареста апостола в Иерусалиме Павел умело использовал свой статус римского гражданина и полученное в юности образование при защите перед судом синедриона и римского наместника. В отношении римского гражданства семьи апостола существует несколько версий, наиболее вероятной из которых считается предоставление ей такового в числе наиболее богатых и влиятельных жителей Тарса. Результатом судебного расследования было решение прокуратора Иудеи удовлетворить апелляцию Павла и отправить его в Рим на суд императора. Как для местной власти, так и для апостола это было оптимальным вариантом в сложившейся ситуации.
\end{abstract}

Ключевые слова: христианство, апостол Павел, римское гражданство, арест, суд, апелляция.

Для цитирования: Парфенов В.Н., Литовченко Е.В. 2020. Апостол Павел в Иудее: последний визит. Via in tempore. История. Политология, 47 (4): 683-692. DOI: 10.18413/2687-0967-2020-47-4683-692.

\section{Apostle Paul in Judaea: the last vizit}

\author{
Victor V. Parfenov, Elena V. Litovchenko \\ Saratov orthodox theological seminary, \\ 92 Michurina St., Saratov, 410028, Russia; \\ Penza theological seminary, \\ 4 Perekop St., Penza, 440023, Russia; \\ Belgorod National Research University, \\ 85 Pobeda St., Belgorod, 308015, Russia \\ E-mail: vparfenov@list.ru, Litovchenko@bsu.edu.ru
}

\begin{abstract}
The article analyzes the history of the arrest of the Apostle Paul in Jerusalem and his detention in Judea. Paul skillfully used his status as a Roman citizen and his early education, both Greek and traditional religious, to defend himself before the Sanhedrin and the Roman Governor. There are several versions regarding the acquisition of Roman citizenship by the Apostle family, the most likely of which is the granting of Roman citizenship to them among the wealthiest and most influential residents of Tarsus, which was a common practice at the end of the Republic and later. The result of the judicial investigation was the decision of the Procurator of Judea to grant Paul's appeal and send him to Rome for trial by the Emperor. This was an optimal option for both the local authorities and the Apostle, since his release from custody or execution by the decision of the Procurator threatened the latter with unpredictable consequences. The trial of Paul by the Sanhedrin entailed certain death, due to the gravity of the charges against him of inciting sedition and blasphemy.
\end{abstract}

Keywords: Christianity, Apostle Paul, Roman citizenship, arrest, trial, appeal. 
For citation: Parfjonov V.N., Litovchenko E.V. 2020. Apostle Paul in Judaea: the last vizit. Via in tempore. History and political science, 47 (4): 683-692 (in Russian). DOI: 10.18413/2687-0967-2020-474-683-692.

Внешняя сторона событий, связанных с визитом Павла в Иерусалим, его арестом, последующим препровождением в Кесарию Приморскую (где находилась резиденция прокуратора Иудеи), двухлетним заключением в ожидании суда, решением нового наместника отправить апостола в Рим знакома любому интересующемуся читателю из Деяний апостолов (автором этого произведения, вошедшего в канон Нового Завета, традиционно считается евангелист Лука). Однако мотивы поведения самого Павла, особенности его положения, связанные с двойным гражданством (Тарса и Рима), отношение римских должностных лиц к нему и его обвинителям, насколько нам известно, специальному анализу в отечественной научной литературе не подвергались.

Сложность данной проблемы определена уже характером источниковой базы. К примеру, в «Деяниях апостолов» «все хронологические маркеры относительны - абсолютные даты отсутствуют полностью» [Humphries, 2006, p. 126]. Таким образом, в отношении хронологии событий приходится обходиться предположениями. К примеру, еще В.В. Болотов полагал, что арест и заключение Павла в Палестине относятся к 56-58 гг., «осенью 58 г. (а не 60 или 61) отправлен был из Кесарии в Рим ... и летом-осенью 62 г., может быть, уже скончался мученически» [Болотов, 1903, с. 65, прим. 13]. А. Робертсон относит прибытие Павла в Рим к 56 г. [Робертсон, 1959, с. 186, прим. 1], следовательно, арест апостола в Иерусалиме должен относиться самое позднее к 54 г. С. Баккиокки датирует это событие поздней весной 57 или 58 г. [Bacchiocchi, 1983, p. 18]. По мнению Б. Шоу, Павел был арестован, «видимо, около 58 г. (но, возможно, даже годом или двумя ранеe)» [Show, 2015, p. 76]. Авторы статьи о Павле в «Энциклопедии античного христианства» прямо не датируют его депортацию в Рим, но из приведенной ими хронологии наместничества Феста в Иудее (58-62 гг.) вытекает, что она относится к 58 г. [Loi, Amata, 2014 , p. 99]. В сущности, этот разнобой объясняется желанием или нежеланием авторов привязать казнь Павла к хорошо известному событию - Великому пожару Рима в 64 г. и последовавшему за ним гонению Нерона на христиан. Поэтому вопрос приходится оставить открытым, хотя в современной науке отмечено, что связь смерти Павла с гонением Нерона представляется сомнительной [Clarke, 2008, p. 870].

Как хорошо известно, из затруднительных ситуаций Павла выручало римское гражданство (Деян. 16:37-39; 22:25-29). Естественно, возникает вопрос, каким образом этот «еврейский интеллектуал и палаточный мастер» [Rüpke, 2018, p. 324] стал римским гражданином по праву рождения, что он с гордостью подчеркнул в разговоре с военным

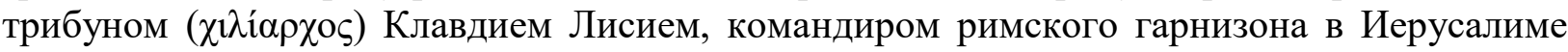
(Деян. 22:27-28).

Статус римского гражданина в I в. н. э. еще значил немало, не случайно тот же начальник гарнизона, судя по имени, этнический грек, подчеркнул, что купил это граж-

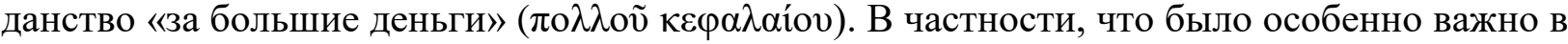
данном случае, римское гражданство предполагало освобождение от телесных наказаний, пыток, наиболее позорных и мучительных видов казни в случае смертного приговора [Mommsen, 1899, 921; Adams, 2008, p. 313 f.] ${ }^{1}$.

Примечательно, однако, что, как отметил В. Маротта, Павел, по его собственным словам, трижды подвергался бичеванию (2 Кор. 11:23-25), и это без учета того, что он претерпел от рук иудеев. Здесь следует отметить, что этот вид наказания практиковался

1 «Римское гражданство в античном мире было желанным сокровищем, обеспечивавшим его обладателю многочисленные права и привилегии, которые были недостижимы для типичного провинциала» [Adams, 2008, p. 326]. 
именно римлянами (Деян. 16:22-23). По мнению исследователя, «эти факты вовсе не доказывают, что у Павла не было гражданства, они лишь подтверждают, насколько сложным было отстаивание им своих прав» [Marotta, 2015, p. 250].

Однако тот же автор обоснованно указывает, что во время инцидента в Филиппах, городе, который имел статус римской колонии, Павлу, который вспоминает об этом в послании фессалоникийцам (1 Фес. 2:2) стоило, как и его компаньону, вовремя заявить о своем статусе civis Romanus, чтобы избежать физического насилия со стороны местных властей, но оба они сделали это только post eventum [Marotta, 2015, p. 250, n. 15].

Действительно, своевременного заявления о недопустимости наказания римского гражданина без соответствующего судебного приговора было бы достаточно, чтобы не допустить избиения. Это подтверждается как поведением магистратов Филипп, узнавших о статусе Павла и Силы (Деян. 16:37-39), так и реакцией римских офицеров (центуриона и военного трибуна) в Иерусалиме, собиравшихся «с пристрастием» допросить виновника смуты среди иудеев (Деян. 22:25-29). Собственно говоря, и приказ Клавдия Лисия бичевать Павла объясняется тем, что последний на греческом языке сообщил ему, что является иудеем и гражданином киликийского города Тарса (Деян. 21:37-39), а с провинциалами в подобных случаях явно не церемонились. Поэтому можно допустить, что нежелание Павла (хотя бы в некоторых случаях) вовремя произнести спасительное «civis Romanus sum!» объясняется особенностями его характера и желанием «пострадать за Христа» ${ }^{2}$.

Интересный и психологически убедительный анализ поведения как Павла при его аресте в Иерусалиме, так и римских офицеров содержится в исследовании С. Адамса [Adams, 2008, p. 324 f.]. Основные его идеи таковы.

Ошибка римских офицеров, намеревавшихся бичевать Павла, вполне объяснима. Когда толпа в Иерусалиме намеревалась растерзать Павла и римские солдаты вырвали оратора из рук иудеев, обстоятельства подтверждали внутрииудейскую природу этого конфликта. Теоретически существовала возможность, что в Иерусалиме могли быть римские граждане из числа потомков иудейских пленников - после падения города, взятого сначала Помпеем (63 г. до н. э.), затем полководцем Антония Гаем Сосием (37 г. до н. э.), - получивших впоследствии свободу и ограниченные гражданские права в результате манумиссии. Но поскольку подобная возможность была крайне маловероятна, да и отношение иудеев к Риму было вполне однозначным, то, скорее всего, ни начальнику гарнизона, ни его подчиненным даже в голову не приходило, что в данном случае они могут иметь дело с римским гражданином.

Во-вторых, Павел представился командиру как иудей и гражданин Тарса. Офицер должен был, во всяком случае, полагать: если бы возмутитель спокойствия обладал римским гражданством, он бы признался в этом сразу или почти сразу после задержания. Объяснение того, что он в этом отношении не торопился, может заключаться в том, что он хотел оказаться вне пределов слышимости буйной, враждебно настроенной толпы иудеев, так как такое признание «нанесло бы серьезный ущерб его делу и подтвердило бы их наихудшие подозрения. Поэтому Павел мудро приберег свое римское гражданство до момента, когда оно могло принести ему наибольшую пользу и не ухудшило бы и без того напряженную ситуацию» [Adams, 2008, p. 324 f.] ${ }^{3}$.

${ }^{2}$ Соответствующий душевный настрой Павла отмечен в Новом Завете (Деян. 21:11-14). Согласно Деяниям апостолов, после своего обращения в христианство «Павел стал столь ревностен в прокламировании имени Иисуса как Господа, что он постоянно привлекался к суду перед римскими властями различных провинций на основании того, что de facto он являлся нарушителем римского мира и порядка». При этом «нельзя сказать, что Павел когда-либо намеренно стремился к возбуждению беспорядков» [Cassidy, 2001, p. 129].

${ }^{3}$ Как отметил Б. Шоу, объявление в нужный момент о своем римском гражданстве было тактикой, которую Павел несколько раз с успехом использовал [Show, 2015, p. 76]. В. Маротта тоже отмечает: «Во время своих путешествий Павел для защиты собственной свободы и физического самочувствия от карательной власти полиции и судебных инстанций городов и провинций римского Востока не молчал, 
Разумеется, римские власти в других городах были не настолько наивны, чтобы поверить Павлу на слово. Прецедентов, когда то или иное лицо делало ложное заявление о своем римском гражданстве, чтобы избежать наказания или хотя бы отсрочить его, к тому времени имелось столько, что император Клавдий распорядился в таких случаях предавать виновных смерти за Эсквилинскими воротами Рима (Suet. Claud. 25.3).

Поэтому Павел, безусловно, должен был доказать, что является римским гражданином, предъявив соответствующий документ. Что представлял собой этот документ, остается только догадываться. Это мог быть diploma civitatis Romane, «маленький диптих, удостоверяющий его рождение и регистрацию в качестве гражданина», или нечто подобное; точный ответ на этот вопрос при современном состоянии источников невозможен [Sherwin-White, 1973, p. 247 ff.; Adams, 2008, p. 326; Marotta, 2015, p. 249].

Что же касается происхождения римского гражданства «апостола язычников», то по этому поводу существуют различные мнения ${ }^{4}$. Понятно, что у Павла, бывшего римским гражданином по праву рождения, гражданства был удостоен его отец, дед или даже прадед, неизвестно только, за какие заслуги. Возможные варианты довольно многочисленны. Предполагается, что предки Павла имели какие-то политические или военные заслуги перед Римом в годы гражданской войны или сразу после нее. Далее, поскольку сам Павел вместе с семьей единоверцев занимался изготовлением палаток в Коринфе (Деян.

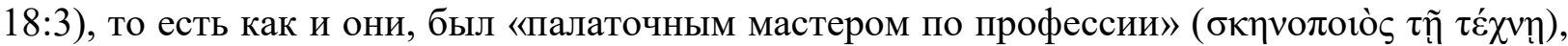
следовательно, ремесло это было наследственным и гражданство могло быть получено за поставки палаток римским войскам, расквартированным в Киликии или Сирии [Робертсон, 1959, с. 148]. Наименее вероятный вариант заключается в том, что юридическое положение Павла и его близких восходит к manumissio, то есть апостол был потомком отпущенного на волю раба [Marotta, 2015, p. 251 ff.].

Более тщательно разобраться в этом сюжете попытался С. Адамс. С его точки зрения, если учесть отношение иудеев к римлянам, маловероятно, что семья Павла приобрела гражданство в результате военной службы Риму. Можно отвергнуть и версию манумиссии - едва ли отец или дед Павла мог оказаться среди еврейских пленников после взятия римлянами Иерусалима в 63 или 37 г. до н. э., быть отпущенным на волю и вернуться в Тарс создавать семью.

Исследователь полагает: «Наиболее вероятно, что гражданством была награждена семья - полководцем или императором, вероятнее всего, Помпеем, - вследствие ее влиятельности или услуги, оказанной Риму» [Adams, 2008, p. 320]. В данном случае подразумевается кампания Помпея против пиратов в 67 г. до н. э. В обоснование своего предположения Адамс ссылается на мнение А.Н. Шервин-Уайта о том, что Цезарь и Август практиковали предоставление римского гражданства «наиболее богатым и влиятельным гражданам других национальностей» [Sherwin-White, 1973, p. 225 ff.].

когда было уместно и необходимо, о своем статусе римского гражданина; он, скорее, успешно эксплуатировал его, когда того требовали интересы его апостолата» [Marotta, 2015, p. 249 f.].

${ }^{4}$ Скептики вообще считают римское гражданство Павла выдумкой автора «Деяний апостолов», которая понадобилась, чтобы сделать Павла более приемлемым для язычников, а само произведение - более остросюжетным. Однако можно согласиться с С. Адамсом, что столь крайняя точка зрения несостоятельна, поскольку апелляция Павла к императорскому суду, защита перед трибуналом наместника и путешествие в Рим целиком зависят от его римского гражданства. Не доверять римскому гражданству Павла значит полностью не доверять всему нарративу, как и заявлениям автора в начале его труда (Лк. 1:1-4; Деян. 1:1). Современные библеисты считают Евангелие от Луки и Деяния апостолов двумя частями единого произведения, написанного одним автором [Adams, 2008. p. 315]. А. Робертсон, напротив, настроен крайне скептически: «На самом деле все эти речи сфабрикованы автором «Деяний». ... Поскольку гл. 22-26 состоят в основном из этих речей, то их достоверность не выше достоверности занимательного исторического романа» [Робертсон, 1959, с. 181]. Этот гиперкритицизм, характерный для марксистской и протестантской историографии раннего христианства, едва ли можно в данном случае разделить: не доверять имеющимся источникам можно лишь при наличии очень веских оснований, а не спекулятивных заключений. 
Но здесь неизбежно возникает еще один вопрос: насколько богаты и влиятельны были ближайшие родственники Павла по мужской линии? Если сам он, как видно из эпизода в Коринфе, обладал навыками квалифицированного ремесленника, то следует ли относить его семью к городской верхушке Тарса? Скорее всего, ответ должен быть положительным. Если семья владела крупной мастерской по изготовлению палаток, то она была достаточно состоятельной, чтобы желать дать Павлу греческое образование [Pitts, 2007, p. 90]. Интересно, что это образование, высокий уровень которого был отмечен даже скептически настроенным римским наместником (Деян. 26:24), будущий «апостол язычников» получил именно в Tapce [Pitts, 2008, p. 19-50; 2014, p. 75-82; 2016, p. 43-67] ${ }^{5}$.

Теперь мы подходим к неизбежному вопросу об отношении местных властей к Павлу и проповедуемому им учению об Иисусе Христе. Еще В.В. Болотов заметил: «Возмущения» иудеев против Павла в нескольких городах Азии и Европы - бесспорный факт;

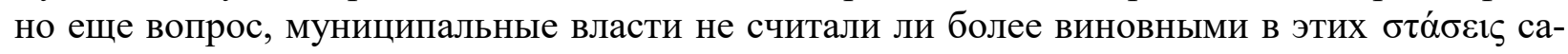
мих иудеев, чем Павла» [Болотов, 1903, с. 70, прим. 20].

В современной историографии мнения по этому поводу разделились. Так, Я. Энгберг отмечает, что на основе анализа имеющихся источников о деятельности апостола Павла можно заключить, что христиане встречали широкое (popular) сопротивление со стороны как иудеев, так и язычников. Более того, негативно к новому религиозному течению относились и «римские должностные лица с локальной (колониальной), региональной (провинциальной) и, возможно, даже общегосударственной (имперской) юрисдикцией. И, самое важное, своим читателям Павел не предоставляет такую конфронтацию как недоразумение; скорее, показано как само собой разумеющееся, что властители мира ceго (the leaders of this world) время от времени препятствовали избраннику Божию (Gods elect) (курсив автора. - В.П.)» [Engberg, 2007, p. 142. Cp.: Lampe, 2015, p. 117, n. 20].

Признавая ценность этого наблюдения, следует оговориться: для того чтобы разобраться в сущности нового религиозного течения, римским властям потребовалось время, причем достаточно длительное ${ }^{6}$. Когда они разобрались, это стоило Павлу головы в буквальном смысле слова, поскольку в его миссионерской деятельности антиримский аспект при желании (и должной «экспертизе» со стороны ортодоксальных иудеев, его обвинителей) найти было вполне возможно [Elliott, 2004, p. 67-88; Ramsaran, 2004, p. 89-102; Wright Knust, 2004, 155-174, esp. 156; Price, 2004, 175-183, esp. 182 f.].

Но в первые десятилетия христианства, по мнению С. Баккиокки, отношение Рима к христианству было иным. Обычно считается, что римские императоры и администраторы до начала 60 -х гг. I в. н. э. либо игнорировали христиан, либо относились к ним как к одной из иудейских сект. Автор полагает, что в действительности картина была несколько иной. С его точки зрения, римские власти достаточно рано поняли «базовое различие между политически ориентированным иудейским мессианистским движением и неполитической природой христианства», поэтому некоторое время относились к последнему достаточно терпимо [Bacchiocchi, 1983, p. 3]. Это, полагает исследователь, доказывается даже обозначением нового движения прилагательным Christianus с чисто латинским суффиксом -ian-; термин, по его мнению, возник в окружении Вителлия, наместника Сирии времен Тиберия, что подтверждает неплохую информированность римских властей в от-

${ }^{5}$ Согласно традиционной точке зрения, Павел учился в Иерусалиме [Асмус, 2009, с. 9; Loi, Amata, 2014, p. 99]. Однако его слова в речи перед иудеями у храма скорее свидетельствуют в пользу Тарса: 'Еүஸ́

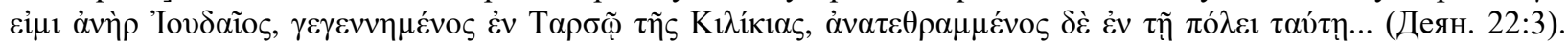
Подробно этот вопрос рассмотрен в диссертации С. Питтса, который, в противоположность мнению многих исследователей, полагает, что традиционное греческое образование Павел получил в Тарсе, а в Иерусалим прибыл учиться иудейской мудрости у Гамалиила, что, впрочем, не исключает продолжения им там не завершенного на родине эллинистического обучения [Pitts, 2007, p. 89 ff., 155-157].

${ }^{6}$ С. Баккиокки доказывает, что terminus post quem - 62 г., предположительный год казни Павла [Bacchiocchi, 1983, p. 23]. Этим же годом, тоже предположительно, датировал казнь апостола еще В.В. Болотов [Болотов, 1903, с. 65 , прим. 13; с. 69]. 
ношении возникшего религиозного течения [Bacchiocchi, 1983, p. 12] ${ }^{7}$. Соответственно, по мнению ученого, «сдерживая и ограничивая иудейские акции против христианства, римские власти покровительствовали экспансии последнего» [Bacchiocchi, 1983, p. 21].

Точка зрения эта, конечно, интересна, но спорна, виной чему может быть состояние источников. Если же исходить из имеющейся информации, то в лучшем случае речь может идти не о римской администрации вообще, а об отдельных, наиболее эрудированных в области восточных религий и дальновидных ее представителях, тогда как отношение центральной власти к христианам и христианству еще толком не определилось (за ненадобностью такого определения).

Додуматься до того, чтобы противопоставить христианство (в его, по сути дела, младенческом состоянии) иудаизму мог, допустим, тот же Сенека, антииудейские взгляды которого не были секретом (Augustin. De civ. Dei. VI.11); вероятно, мог спустя десятилетия император Домициан, тоже настроенный соответствующим образом (Suet. Dom. 12.2) [cp.: Bacchiocchi, 1983, p. 22; Парфенов, 2016, с. 180 сл.]. Как бы то ни было, дальнейшего развития такая политика не получила: до Миланского эдикта государство и общество должны были долго еще дозревать.

Но римским магистратам в массе своей эти различия во взглядах ортодоксальных иудеев и, как они полагали, иудейских же «сектантов» были тогда глубоко безразличны, лишь бы не нарушался общественный порядок на вверенной их надзору и попечению территории ${ }^{8}$. Подтверждается это историей суда над Павлом в Иудее и его последующей депортацией в Рим.

Согласно Деяниям апостолов, начальник иерусалимского гарнизона, вырвав Павла из рук иудейских фанатиков, намеревавшихся его растерзать, отправил виновника волнений в сопровождении сильного конвоя в резиденцию прокуратора Иудеи М. Антония Феста Кесарию Приморскую (Caesarea Maritima) ${ }^{9}$. Однако в сопроводительном письме военный трибун Лисий, в отличие от того, что утверждает Б. Шоу [Show, 2015, p. 76], не обвиняет Павла в возбуждении мятежных настроений. Напротив, если верить автору Деяний, начальник иерусалимского гарнизона указывает, что тот, по его мнению, не совершил ни-

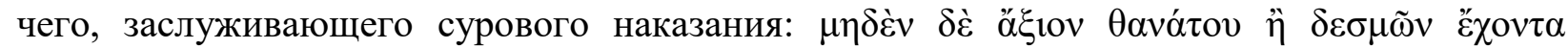
है $\gamma \kappa \lambda \eta \mu \alpha(23: 29)$.

Против Павла иудеи выдвинули обвинения политического и религиозного характе-

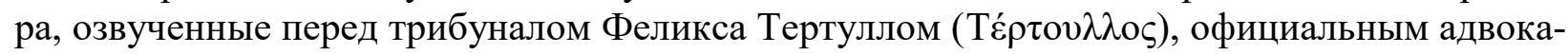
том Синедриона. Надо сказать, данный обладатель римского имени свое дело знал: оба вида обвинений угрожали Павлу смертью.

В политическом отношении «обвинение Павла в том, что он был «агитатором», возбуждающим мятежи, едва ли могло игнорироваться римскими должностными лицами, которые внимательно отслеживали сектантский националистический фермент, что будоражил иудейский мир в то время» [Bacchiocchi, 1983, p. 18].

В отношении религиозном Павла обвинили в попытке «осквернить храм» введением в него язычников, что влекло за собой, как об этом предупреждала надпись у входа, казнь виновных, причем в данном случае, как можно заключить по имеющейся информации (Ios. Antt. XV.11.5), санкции на нее римлян не требовалось.

${ }^{7}$ Кстати, В.В. Болотов подчеркивал, что термин «христиане» никак не мог выйти из иудейской

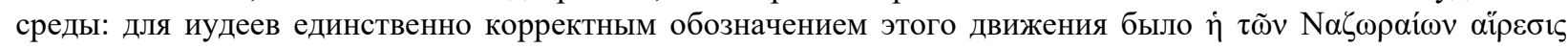
[Болотов, 1903, с. 68, прим. 17].

${ }^{8}$ Даже если они знали, что «иудеи и христиане - это не совсем одно и то же» [Lampe, 2015, p. 117, n. 20].

9 Этому предшествовала попытка представить его на суд синедриона, когда Павел, искусно используя разногласия между фарисеями и саддукеями, добился того, что часть фарисеев приняла его

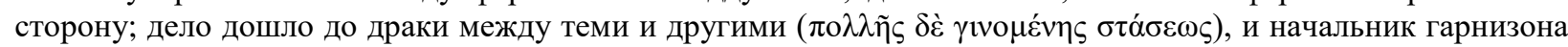
приказал солдатам увести его в казарму (Деян. 23:6-10). 
Полностью сознавая политическую сущность всего судебного дела, Павел в первую очередь приложил все усилия к опровержению обвинения в мятеже: «Линия защиты, принятая Павлом как перед иудейскими, так и перед римскими властями, заключалась в том, чтобы свести основания для его ареста исключительно к религиозным причинам...» [Bacchiocchi, 1983, p. 18 f., n. 49]. Надо сказать, это вполне удалось, причем не без снисходительного отношения к нему со стороны представителей римской администрации, которые должны были принять решение по его делу (царь Агриппа II, правнук Ирода Великого, в данном случае играл роль консультанта при новом прокураторе Фесте).

Основные доводы защиты Павла заключались в том, что он не совершил ничего дурного ни против иудейского закона, ни против храма, ни против императора (Деян. 25:8). В результате Фест приходит к выводу, что подсудимый действительно не виновен в чем-либо предосудительном (25:25-26). Созванное наместником совещание с участием Агриппы II, Береники и других компетентных лиц после речи Павла приходит к выводу, что «этот человек не совершил ничего, достойного смерти или уз» (26:31), а царь выразил Фесту свое мнение, что подсудимого следовало бы освободить, но это невозможно из-за его же собственной апелляции к императору (26:32).

С. Баккиокки делает далеко идущий вывод в отношении позиции римских официальных лиц по этому делу: «Никто из них, от трибуна Лисия до прокураторов Феликса, Феста и царя Агриппы, не принимал всерьез политическое обвинение в мятеже. Почему? Предположительно потому, что они достаточно знали о неполитической, мирной природе христианского мессианистского движения. ... Живой интерес к христианскому учению у людей, подобных царю Агриппе, как и последовательное отклонение обвинения в мятеже и осквернении храма всеми вышеуказанными римскими должностными лицами, которые принимали участие в суде над Павлом в Палестине, подтверждает хорошее знакомство римлян с христианством и терпимость по отношению к нему» [Bacchiocchi, 1983, p. 19 f.].

Думается, автор преувеличивает здесь как интерес иудейской верхушки к новому религиозному течению, так и степень осведомленности о нем римских магистратов, которых, кроме личных интересов, должно было беспокоить прежде всего спокойствие вверенных им подданных. Признав недоказанными обвинения в адрес Павла, они исходили из формально-юридической стороны дела и в этом отношении были совершенно правы. Терпимость по отношению к христианству здесь совершенно ни при чем, поскольку оно как таковое если и могло их заинтересовать, то разве что в последнюю очередь.

В заключение можно задаться вопросом, насколько правомерной была отправка Павла в Рим? По мнению Брента Шоу, он оказался в столице империи лишь «потому, что таким было произвольное решение римского наместника в Иудее, который отправил его в Рим вместо того, чтобы казнить на месте» [Show, 2015, p. 78].

Едва ли с этим можно согласиться. С одной стороны, выдвинутые ортодоксальными иудеями против Павла обвинения, в первую очередь политические, были слишком серьезными, чтобы Фест взял на себя смелость освободить Павла - это могло быть чревато новой вспышкой массовых волнений на религиозной почве и доносом в Рим об освобождении государственного преступника ${ }^{10}$. С другой - казнь римского гражданина, да еще по столь «резонансному делу», могла вызвать нежелательные последствия для самого наместника ${ }^{11}$.

Если учесть, что римские власти вообще остерегались предпринимать действия, способные затронуть религиозные чувства их столь беспокойных подданных, какими бы-

${ }^{10}$ Не случайно предшественник Феста отложил суд на неопределенный срок, оставив апостола в тюрьме, хотя и на льготных условиях, и едва ли дело здесь было только в коррумпированности Феликса, как старается уверить читателя автор Деяний (24:26).

11 Брент Шоу полагает, что Павел мог воспользоваться своим правом апелляции к императору только с позволения наместника [Show, 2015, p. 77]. Однако делегирование императором своим наместникам сенаторского и тем более всаднического ранга права присуждать к смерти римского гражданина (ius gladii) надежно зафиксировано только со времени Адриана [Marotta, 2015, р. 257]. Так что в данном случае Фесту рисковать не стоило. 


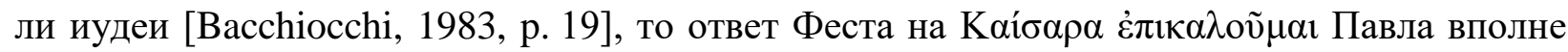

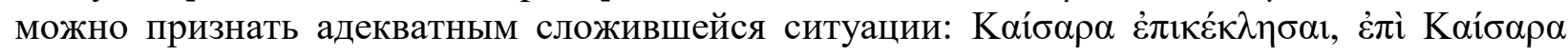

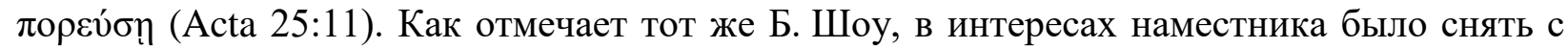
себя ответственность за столь спорный случай [Show, 2015, p. 77].

\section{Список литературы}

1. Асмус В.Ф. 2009. Лекции по истории Церкви. М., Свято-Тихоновский богословский университет, 95.

2. Болотов В.В. 1903. Гонение на христиан при Нероне. Христианское чтение. 1: 56-75.

3. Парфенов В.Н. 2016. Долгое эхо Иудейской войны: Домициан и родственники Иисуса Христа «по плоти». Труды Саратовской православной духовной семинарии. Вып. Х: 164-182.

4. Робертсон А. Происхождение христианства. Пер. с англ. М., 1959, 322.

5. Adams S.A. 2008. Paul the Roman Citizen: Roman Citizenship in the Ancient World and its Importance for Understanding Acts 22: 22-29. In: S.E. Porter (ed.). Paul: Jew, Greek, and Roman. Leiden, Brill, 309-326.

6. Bacchiocchi S. 1983. Rome and Christianity until A. D. 62. Andrews University Seminary Studies. Vol. 21. 1: 3-25.

7. Cassidy R.J. 2001. Christians and Roman Rule in the New Testament: new perspectives. New York, Crossing Publishing Company, 159.

8. Clarke G.W. 2008. The origin and spread of Christianity. In: Cambridge Ancient History. $2^{\text {nd }}$ ed. Vol. X. Cambridge, University Press: 848-872.

9. Elliott N. 2004. The Apostle Paul's Self-Presentation as Anti-Imperial Performance. In: R.A. Horsley (ed.). Paul and the Roman Imperial Order. Harrisburg - London - New York, Trinity Press International: $67-88$.

10. Engberg J. 2007. Impulsore Chresto. Opposition to Christianity in the Roman Empire. Transl. by G. Carter. Frankfurt am Main, Peter Lang, 345.

11. Lampe P. 2015. Roman Christians under Nero (54-68 C. E.). In: A. Puig. I. Tàrrech, J.M.G. Barclay, J. Frey (eds.). The Last Years of Paul. Essays from the Tarragona Conference June 2013. Tübingen. Mohr - Siebeck: 111-130.

12. Loi V., Amata B. 2014. Paulus, apostle. I. The man and his evangelic work. Encyclopedia of Ancient Christianity. Vol. 3: 98-99.

13. Marotta V. 2015. St. Paul's Death. Roman Citizenship and summa supplicia. In: A. Puig. I. Tàrrech, J.M.G. Barclay, J. Frey (eds.). The Last Years of Paul. Essays from the Tarragona Conference June 2013. Tübingen. Mohr - Siebeck: 247-270.

14. Mommsen Th. 1899. Römisches Strafrecht. Leipzig, Duncker \& Humblot, 1104.

15. Pitts A.W. 2007. Paul and Hellenistic Education: Assessing Early Literary, Rhetorical and Philosophical Influences. Diss. Hamilton (Ontario), McMaster Divinity College, 176.

16. Pitts A.W. 2008. Hellenistic Scools in Jerusalem and Paul's Rhetorical Education. In: S.E. Porter (ed.). Paul's World. Leiden, Brill: 19-50.

17. Pitts A.W. 2014. Tarsus or Jerusalem? A Syntactic Argument for Tarsus as the City of Paul's Youth in Acts 22:3. Filologia Neotestamentaria. Vol. 27: 75-82.

18. Pitts A.W. 2016. Paul in Tarsus. Historical Factors in Assessing Paul's Early Education. In: S.E. Porter, B. Dyer (eds.). Paul and Ancient Rhetoric: Theory and Practice in the Hellenistic Context. Cambridge, University Press: 43-67.

19. Porter S.E., Pitts A.W. 2008. Paul's Bible, his Education and his Access to the Scriptures of Israel. Journal of Greco-Roman Christianity and Judaism. Vol. 5: 99-41.

20. Price S.R.F. 2004. Response. In: Paul and the Roman Imperial Order. Harrisburg - London New York, Trinity Press International: 175-183.

21. Ramsaran R.A. 2004. Resisting Imperial Domination and Influence: Paul's Apocaliptic Rhetoric in 1 Corinthians. In: Paul and the Roman Imperial Order. Harrisburg - London - New York, Trinity Press International: 89-102.

22. Rüpke J. 2018. Pantheon: a new history of Roman religion. Transl. by D.M.B. Richardson. Princeton - Oxford, Princeton University Press, 573.

23. Shaw B. 2015. The Myth of the Neronian Persecution. Journal of Roman Studies. Vol. 105: 73-100. 
24. Sherwin-White A.N. 1973. The Roman Sitizenship. $2^{\text {nd }}$ ed. Oxford, Clarendon Press, X, 486.

25. Wright Knust J. 2004. Paul and the Politic of Virtue and Vice. In: Paul and the Roman Imperial Order. Harrisburg - London - New York, Trinity Press International: 155-174.

\section{References}

1. Asmus V.F. 2009. Lektsii po istorii Tserkvi [Lectures on the history of the Church]. Moskwa, Svyato-Tikhonovskij bogoslovskij universitet, 95 (in Russian).

2. Bolotov V.V. 1903. Gonenie na christian pri Nerone [The persecution of Christians under Nero]. Christianskoje chtenie. 1: 56-75 (in Russian).

3. Parfjonov V.N. 2016: Dolgoe echo Iudeiskoi voiny: Domitsian i rodstvenniki Iisusa Christa «po ploti» [A long echo of the Jewish war: Domitian and the relatives of Jesus Christ «in the flesh»]. Trudy Saratovskoi pravoslavnoi dukhovnoi seminarii. Vyp. X: 164-182 (in Russian).

4. Robertson A. 1959. Proiskhozhdenie christianstva [The Origins of Christianity]. Per. s angl. Moskwa, 322 (in Russian).

5. Adams S.A. 2008. Paul the Roman Citizen: Roman Citizenship in the Ancient World and its Importance for Understanding Acts 22: 22-29. In: S.E. Porter (ed.). Paul: Jew, Greek, and Roman. Leiden, Brill, 309-326.

6. Bacchiocchi S. 1983. Rome and Christianity until A. D. 62. Andrews University Seminary Studies. Vol. 21. 1: 3-25.

7. Cassidy R.J. 2001. Christians and Roman Rule in the New Testament: new perspectives. New York, Crossing Publishing Company, 159.

8. Clarke G.W. 2008. The origin and spread of Christianity. In: Cambridge Ancient History. $2^{\text {nd }}$ ed. Vol. X. Cambridge, University Press: 848-872.

9. Elliott N. 2004. The Apostle Paul's Self-Presentation as Anti-Imperial Performance. In: R.A. Horsley (ed.). Paul and the Roman Imperial Order. Harrisburg - London - New York, Trinity Press International: $67-88$.

10. Engberg J. 2007. Impulsore Chresto. Opposition to Christianity in the Roman Empire. Transl. by G. Carter. Frankfurt am Main, Peter Lang, 345.

11. Lampe P. 2015. Roman Christians under Nero (54-68 C. E.). In: A. Puig. I. Tàrrech, J.M.G. Barclay, J. Frey (eds.). The Last Years of Paul. Essays from the Tarragona Conference June 2013. Tübingen. Mohr - Siebeck: 111-130.

12. Loi V., Amata B. 2014. Paulus, apostle. I. The man and his evangelic work. Encyclopedia of Ancient Christianity. Vol. 3: 98-99.

13. Marotta V. 2015. St. Paul's Death. Roman Citizenship and summa supplicia. In: A. Puig. I. Tàrrech, J.M.G. Barclay, J. Frey (eds.). The Last Years of Paul. Essays from the Tarragona Conference June 2013. Tübingen. Mohr - Siebeck: 247-270.

14. Mommsen Th. 1899. Römisches Strafrecht. Leipzig, Duncker \& Humblot, 1104.

15. Pitts A.W. 2007. Paul and Hellenistic Education: Assessing Early Literary, Rhetorical and Philosophical Influences. Diss. Hamilton (Ontario), McMaster Divinity College, 176.

16. Pitts A.W. 2008. Hellenistic Scools in Jerusalem and Paul's Rhetorical Education. In: S.E. Porter (ed.). Paul's World. Leiden, Brill: 19-50.

17. Pitts A.W. 2014. Tarsus or Jerusalem? A Syntactic Argument for Tarsus as the City of Paul's Youth in Acts 22:3. Filologia Neotestamentaria. Vol. 27: 75-82.

18. Pitts A.W. 2016. Paul in Tarsus. Historical Factors in Assessing Paul's Early Education. In: S.E. Porter, B. Dyer (eds.). Paul and Ancient Rhetoric: Theory and Practice in the Hellenistic Context. Cambridge, University Press: 43-67.

19. Porter S.E., Pitts A.W. 2008. Paul's Bible, his Education and his Access to the Scriptures of Israel. Journal of Greco-Roman Christianity and Judaism. Vol. 5: 99-41.

20. Price S.R.F. 2004. Response. In: Paul and the Roman Imperial Order. Harrisburg - London New York, Trinity Press International: 175-183.

21. Ramsaran R.A. 2004. Resisting Imperial Domination and Influence: Paul's Apocaliptic Rhetoric in 1 Corinthians. In: Paul and the Roman Imperial Order. Harrisburg - London - New York, Trinity Press International: 89-102.

22. Rüpke J. 2018. Pantheon: a new history of Roman religion. Transl. by D.M.B. Richardson. Princeton - Oxford, Princeton University Press, 573. 
23. Shaw B. 2015. The Myth of the Neronian Persecution. Journal of Roman Studies. Vol. 105: 73-100.

24. Sherwin-White A.N. 1973. The Roman Sitizenship. $2^{\text {nd }}$ ed. Oxford, Clarendon Press, X, 486.

25. Wright Knust J. 2004. Paul and the Politic of Virtue and Vice. In: Paul and the Roman Imperial Order. Harrisburg - London - New York, Trinity Press International: 155-174.

\section{ИНФОРМАЦИЯ ОБ АВТОРАХ}

Парфенов Виктор Николаевич, доктор исторических наук, профессор кафедры церковной истории Саратовской православной духовной семинарии, г. Саратов; профессор кафедры церковной истории и философии Пензенской духовной семинарии, г. Пенза, Россия

Литовченко Елена Викторовна, кандидат исторических наук, доцент кафедры всеобщей истории Белгородского государственного национального исследовательского университета, г. Белгород, Россия

\section{INFORMATION ABOUT THE AUTHORS}

Victor V. Parfenov, Doctor of Historical Sciences, Professor of the Department of Church History of the Saratov Orthodox Theological Seminary, Saratov; Professor of the Department of Church History and Philosophy of the Penza Theological Seminary, Penza, Russia

Elena V. Litovchenko, Candidate of Historical Sciences, Associate Professor of the Department of General History, Belgorod State National Research University, Belgorod, Russia 